\title{
A Reflection of the Spiritual Leadership's Status in a Transfer of Ritual Process
}

\author{
Rachel Sharaby ${ }^{1}$ \\ ${ }^{1}$ Department of Sociology and Anthropology, Ashkelon Academic College, Ashkelon, Israel \\ Correspondence: Rachel Sharaby, Department of Sociology and Anthropology, Ashkelon Academic College, Ashkelon, \\ Israel.
}

Received: February 28, 2020

Accepted: March 26, $2020 \quad$ Available online: April 23, 2020

doi:10.11114/ijsss.v8i3.4823

URL: https://doi.org/10.11114/ijsss.v8i3.4823

\begin{abstract}
This article presents a phenomenon of ritual dynamics, which Langer et al. (2006) called "transfer of ritual," and the manner in which it influenced the "transfer of spiritual leadership." The article focuses on old spiritual leaders (kessoch) of immigrants from Ethiopia in Israel and their role in the Seged ritual. The Seged is a pilgrimage holiday of the Jews of Ethiopia, celebrated on November 29. It is a day of fasting, purification and prayer, during which the spiritual leaders read from the Torah and prayed for redemption. The findings show that since the early 1980s, the kessoch, who were excluded by the religious establishment, were pushed aside from their status in determining the meaning and character of the Seged. Since the 1990s, young social-political leaders, who were the dominant stream in the community, led changes in the Seged. The intergenerational role inversion in conducting the Seged had significant implications for the contents of the ritual, its structure and the kessoch's status.
\end{abstract}

Keywords: religious priests, Ethiopia, ritual dynamics, leaders, immigration, ethnic minority

\section{Introduction}

\subsection{The Jews of Ethiopia and Their Leadership}

The Jews of Ethiopia (Beta Israel) lived mainly in small rural communities dispersed in north-west Ethiopia, and worked mainly in agriculture (Abbink, 1983, p. 790). They were strict in observing the laws of purification, that were intended to strengthen their identity as a minority group within a multi-ethnic society. A major concept in the family and community life in Ethiopia was respect, where the hierarchy existed according to parameters of age, gender, religious and economic status and role (Poluda, 2007, pp. 10-13).

The Beta Israel communities were closed religious communities headed by their spiritual leaders, the religious priests (kessoch, singular - kess). They had authorities on matters of religion and customs; holding prayers; reading from the Torah (Orit), which was written in the ancient Ge'ez language that was preserved only among the kessoch. They also performed marriage, divorce and burial ceremonies (Sharaby \& Kaplan, 2014, p.12).

The Jews of Ethiopia were cut off from the rest of the Jewish people since the destruction of the First Temple. Their tradition was therefore based on the written Torah given to Moses at the Revelation at Sinai, and their customs are not compatible with the customary law of the religious Jewish world (Shalom, 2012, pp. 59-60). Nonetheless, they suffered many difficulties from the fourteenth to the twentieth centuries, due to their desire to preserve their religious belief (Abbink, 1990, pp. 401-402; Teferi, 2005, p. 180).

The tradition of the Jews of Ethiopia included unique customs and holidays that were not customary in other Jewish communities around the world. The most important of these was the Seged holiday, which is at the focus of the present article. The Seged is a pilgrimage holiday which the Jews of Ethiopia celebrate on November 29. This is a day of fasting, purification and prayer. During the course of this holiday, the religious priests read portions of the Torah and prayed for redemption and a return to Zion.

The Seged reconstructed and symbolized the covenant between the People of Israel and God in Jerusalem, during the "Return to Zion" period under the leadership of Ezra and Nehemiah as well as during the Revelation at Sinai. This, with the aim of strengthening their religious belief and their yearning to immigrate to Israel. (Shalom, 2012, p. 209).

Like any political-social order that imparts legitimization to the leadership, the Seged rituals also strengthened the status 
of the religious priests. They were the main symbol in the ritual system of the Seged, and conducted all of its stages: They prepared their communities for the Seged; purified the mountain; headed the celebrators' procession up the mountain according to an internal hierarchic order; were positioned in a special enclosure on the mountain; conducted the religious ritual; descended the mountain at a the head of the celebrators' procession; fulfilled a major role in the collective holiday meal (Ben-Dor, 1985, pp. 95-97).

These and other activities, and particularly the religious and social messages communicated during the Seged as mediated by the kessoch, imparted meaning to the Jewish community in Ethiopia, constructed consensus around its fundamental values, enabled each person to experience himself as part of the community and strengthened the status of its leaders.

\subsection{Immigration and a Decline in the Religious Priests'Status}

During the 1970s, the political conditions in Israel and in Ethiopia enabled the immigration of the Jews to Israel (Ben-Ezer, 2010). The Jews' journey to Sudan on their way to Israel began in 1977, by walking hundreds of kilometers. This journey involved great tribulations. Conditions in the transition camps in Sudan were also harsh, and their long stay there resulted in great mortality, a disintegration of communities and families (Ben-Ezer, 2010). Since the 1980s, the Jews of Ethiopia were brought to Israel in two mass immigration waves: "Operation Moses" in 1984 and "Operation Solomon" in 1991 (Spector, 2005).

The immigrants from Ethiopia cope with prejudices, discrimination and social alienation that stems from their skin color and cultural otherness (Antebi-Yemini, 2010). The dispute about their Judaism served as another factor for their exclusion in Israel. The immigrants from Ethiopia were, in general, recognized as Jews, but the Judaism of each individual was doubted, due to concern regarding intermarriages. In order to be registered as Jews and receive Israeli citizenship, the immigrants of the first wave were required to undergo conversion, including circumcision and immersion (Antebi-Yemini, 2010). After a long protest, the religious establishment withdrew from its position, and as a compromise, a national marriage registrar was appointed for testing the couple's Judaism when registering for marriage (Corinaldi, 2005).

Casting doubt on their Judaism severely harmed the status of the kessoch in Israel. After a struggle, the religious establishment recognized the kessoch who emigrated from Ethiopia (in 1993) and they now work for a (partial) salary in their communities, within the framework of the religious councils. However, their authorities were restricted, and they are not allowed to handle matters of marriage, divorce, shechita (slaughtering according to Jewish dietary laws), burial, etc. (Sharaby \& Kaplan, 2014, pp. 53-92).

In a study on old kessoch in Israel who were trained for their role and served as heads of communities in Ethiopia, it was found that their status was harmed not only bureaucratically, but also morally (Sharaby \& Kaplan, 2014, pp. 53-92), since the reality of Western-oriented Israel contradicts the patriarchic and organizational values of these leaders. The dominant behavior pattern common among the old kessoch is therefore characterized by despair, helplessness, submission to reality, a feeling of alienation and a deep sense of disrespect.

\subsection{Leadership}

The issue of leadership, how it is consolidated and its influence on the public it leads, has been discussed at length in the research literature (Bass, 2009; Sharaby, 2018). Leadership is consolidated through three main components: the led, the environmental context and the leader (Maccoby, 2009). Researchers have emphasized the characteristics and traits of leaders, such as personal charisma, ability to outline a vision and hope, a person with values (Popper, 2002; Weber, 1979). However, more and more studies stress the led group and the context as having considerable weight in consolidating leadership. Different studies emphasize the group's need for a leader, in particular during times of crisis. During a period of crisis, the community will be drawn to leaders who are perceived as strong and as supplying a sense of security (Popper, 2012; Popper \& Maysless, 2003; Oliver-Lumerman et al., 2018).

According to researches, the cultural context is very important for consolidating the leadership figure. Some cultures regard the leader as having traits of the ability to share, social skills and interpersonal skills. Other cultures place less emphasis on these skills (Hofstede \& Hofstede, 2010). It is impossible to understand leadership and its influence without understanding the cultural context and the way the led think (Hofstede, 2001; Oliver-Lumerman et al., 2018, p. 5). Leadership has a particularly great significance during periods of uncertainty and a reduction in the weight of formal authority at the level of the family and in the broader social frameworks (Popper, 2007).

Recent studies investigated a broader range of social leaders in private and public organizations and also dealt in leaders in nonprofit organizations, which are called "the third sector," as well as social movements (Oliver-Lumerman et al., 2018 , p. 4). In recent years, due to the influence of cultural and global changes, studies have been performed on "spiritual leadership." This leadership is based on the leader's set of values, attitudes and behaviors that create internal 
motivation among the led by turning to the spiritual dimension of their lives. (Fry, 2003; Oliver-Lumerman et al., 2018, p. 5).

Other studies investigate "intercultural leadership," i.e. leadership that includes led from different cultures and normative systems. The intercultural leader has the ability to bridge over cultural differences among the led. (Collard, 2007; Oliver-Lumerman, 2018, p. 5).

\subsection{The Research Hypotheses}

This article discusses old spiritual leaders of immigrants from Ethiopia in Israel and focuses on their role in the ritual system of the Seged holiday. I try to show an effect of ritual dynamics, which Langer et al. (2006) called "transfer of ritual." This concept means the transfer of a ritual from one context to another, as a process of transference that can take place in time or in space.

I hypothesize that the "transfer of ritual" phenomenon influences the status of the immigrants' traditional leaders. I will therefore examine the "transfer of ritual" and the "transfer of ritual leadership" as parallel processes. I further hypothesize that the weakening of the traditional spiritual leadership and the transformation in the religious significance of the Seged, the clear symbol of the kessoch, due to processes of secularization and an intercultural encounter, will generate changes in their status during the Seged.

These changes will be tested in the present article from the perspective of the old kessoch. Since the Jews of Ethiopia realized their aspiration and reached the Holy Land and Jerusalem, for which they yearned during the Seged, I will also test the new meanings which the kessoch imparted to the continuation of the Seged tradition in Israel.

The issue of the leadership of the immigrants from Ethiopia in Israel is crucial for attempting to understand their processes of organization and coping as a minority group with the circumstances of immigration to Israel. The discussion on this leadership will also point to the social position of immigrants and old people in the postmodern reality in immigrant-absorbing societies.

\section{Method}

Different qualitative methods were used in order to achieve the research aims. I performed content analysis of articles that appeared in the Israeli daily press from the 1980s. The newspaper reports were few, the reporting brief, and they comprise an example for the marginal status of the Seged and the ethnic group from Ethiopia in the public sphere in Israel.

The newspaper Yedioth Negat (in Hebrew and in Amharic), which has been published in Israel since 1999 by the Steering Center for Ethiopian Immigrants in the Education System (www.kidum-edu.org.il), served as an important research source.

The study is also based on some participant observations. The first observation I made in the Seged ritual in Jerusalem was in 2006. The ritual comprised a strong anthropological experience for me. It is what in the end motivated me to collect additional primary materials with the aim of writing a paper about the Seged.

\subsection{Participants}

The lack of written sources was to a great extent complemented by semi-structured in-depth interviews with old spiritual leaders of the community. Ten old kessoch, aged 65-83 were interviewed. These kessoch had led their communities also in Ethiopia. I met these leaders within the framework of a journey of interviews that I made with a colleague from 2009 to 2011 in settlements with a large concentration of Ethiopian immigrants. Most of the interviewees immigrated to Israel in the early 1990s and live mainly in peripheral areas. Some had almost complete mastery of Hebrew, and young family members assisted others in translating. The interviews were held in synagogues or in the interviewees' homes.

The main topics raised in the semi-structured interviews referred first of all to the question of the interviewees' status as spiritual leaders in Ethiopia: their roles, authorities and status in the community in everyday life; their position and roles in managing all stages of the ritual system of the Seged holiday; the preparations for the holiday, the procession of their community on foot to the place of the ritual; the ascension to the mountain and the liturgy headed by them; descent from the mountain and the collective meal.

Next I focused, in my questions to the interviewees, on a discussion of issues that referred to the research question, that is, to the roles and position of the kessoch in Israel, in everyday life and in particular during the Seged holiday, from the time they immigrated to Israel until recent years: the location of the religious ritual; the order and content of the ritual; the spreading of the Seged events in the time and space dimensions; the organization of the celebrations; the participants in the celebrations; turning the Seged into a national holiday, etc. 
By means of these questions I tried to examine not only the transformation of the ritual that "immigrated" to Israel with the immigrants from Ethiopia, but rather fundamental issues from the kessoch's point of view: differences of opinion between the religious leaders and the young social-political leaders; their position in the organization of the religious ritual; their reference to the processes of change in the Seged and in the tradition of their community; as well as the interpretations they afforded to the continuity of the Seged with the aim of turning it into something relevant to the new society. Raising the topics on such a linear axis helped me understand the evolution of the status of the spiritual leaders of the immigrants from Ethiopia in Israel from a comparative perspective.

\subsection{The Phenomenological Hermeneutical Method}

The phenomenological hermeneutical method used in the present study attributes importance to understanding, describing and analyzing a social effect through the participants' subjective experience (Chase, 2005; Van Mannen, 2011). The semi-structured in-depth interview may supply information and focused references on the issue chosen by the researcher. However, the researcher also gives the interviewee a chance to express himself and develop issues in directions that the researcher did not foresee (Shkedi, 2003, p. 23).

The oral testimonies were analyzed as customary in a qualitative method based on interviews as the research instrument: transcription of the interviews, encoding of the transcription into topics, creating categories and identifying units of meaning - themes. The great advantage of this technique is that it enables analyzing the interviews according to the categories of meaning that emerge from the interviews, and not according to predetermined categories (Green et al., 2007).

Using a method based on late testimonies has a limitation characteristic of life stories in general (Bilu, 2004, p. 12). There is a tendency, at older ages, to accept events and conflicts that occurred, and to idealize the past. Nonetheless, these primary sources, that comprise an "oral history," are a very important social and cultural text.

\section{Results and Discussion}

\subsection{Differences of Opinion among the Kessoch in the Early Celebrations}

The first Seged celebrations in the early 1980s were characterized by finding the way and by great tensions both within the community and with the establishment, regarding the manner in which the Seged will be shaped in the new reality. The conflicts surrounding the displacement of the traditional holiday to Israel reflect the complex religious, social and political situation of the immigrants from Ethiopia and the differences of opinion as to their "social image" in Israel (Abbink, 1983).

One of the main issues was whether the Seged, that expressed the aspiration of the Jews of Ethiopia for redemption, is superfluous after their immigration to Israel, or whether it should be continued in Israel, and if so, what character should it have: Ethiopian or Israeli? Kess Adiso and others, especially the younger ones, claimed that the idea of celebrating the Seged in Israel is inappropriate, since this was a day of the diaspora that lost its meaning in the Holy Land.

On the background of the doubting of the Judaism of the immigrants from Ethiopia, they also feared that the holiday would point to the religious difference between their community and the Israeli public, and would have a negative effect on them. Kess Adiso and others were also afraid that the celebrations would highlight the presence of these immigrants in Israel and would endanger the secret immigration from Ethiopia (Abbink, 1983, pp. 798-801; Ben-Dor, 1987).

Other activists among the youths of the community supported the existence of some Seged ritual and its conversion into a day of ethnic identification. However, they did not want the holiday to be characterized as too "Ethiopian," because they wanted to avoid stressing the difference between the Ethiopian Jews and the rest of the Jewish communities, and to strengthen their status in Israel (Abbink, 1983, pp. 193, 798; Ben-Dor, 1985).

The few kessoch who lived in Israel at that time did not have an important voice regarding religious issues, since they were dependent on the Israeli rabbis, representatives of the state's religious establishment. It can be seen that already from the first Seged celebrations, the kessoch were pushed from their status and responsibility in everything pertaining to the Seged holiday. Rabbi Menachem, who was born in Ethiopia and served as the Chief Rabbi of the immigrants from Ethiopia, was a representative of the Israeli religious establishment. He was the one who pushed to hold the Seged. In 1980 he turned to the Chief Rabbinate with a request to hold the holiday. His request was supported by Kess Moshe. However, Kess Adiso was opposed (Abbink, 1983, p. 798). Due to the differences of opinion, the first celebrations were celebrated only in a symbolic Seged ritual in Jerusalem (Ben-Dor, 1985, p. 193).

Another essential controversial question was the place and centrality of the Seged ritual. In Ethiopia there was not one ritual center, but rather several places of gathering in central villages, to which Jews from different villages came, and they all ascended a nearby mountain in order to celebrate. In contradistinction, the decision to have one central ritual for the entire community on Mount Zion in Jerusalem was a dramatic change from the custom in Ethiopia. Some of the 
community members viewed the celebration in a central place as a change that intensifies the holiday experience and turns it into a main event of the Jews of Ethiopia in Israel (Josefsberg Ben-Yehoshua, 2013). However, others opposed the new ritual plan.

Kess Adiso expressed concern that the gathering of all members of the community in one ritual place will harm the solidarity of his community, his ability to control it and the serious nature of the sacred day. Therefore, he refused to participate in the main ritual in Jerusalem, and held a separate Seged celebration with his community. He also persuaded another kess to refrain from going to the Seged ritual in Jerusalem (Ben-Dor, 1985, pp. 194-195). In my opinion, Kess Adiso's consistent refusal indicates his brave effort to preserve traditional cultural values as much as he could, vis-à-vis strong forces of change within and without the community.

On a background of the opposition of the community's spiritual leaders to uphold the Seged or its form, and the absence of members of their communities from the ritual, the organizers of the Seged decided, for the first time in 1983, to include the twelve kessoch who lived in Israel at that time in planning the event (Ben-Dor, 1985, p. 195). All the kessoch cooperated, except for the Kess Adiso, who continued in his refusal to participate in a central Seged celebration.

The more central position that was given to the kessoch in managing and organizing the main ritual of the Seged contributed to its success in 1983 (Ben-Dor, 2008, p. 149). The ceremony was later moved to the Government House in Jerusalem, which overlooks the Temple Mount (a holy site in the Old City of Jerusalem, where the Temple was built).

\subsection{Intergenerational Role Inversion}

In the late 1990s the Jewish Agency established the "Israel Association of Ethiopian Jews" and supported its activities, including the organizing of the Seged. During the 1990s the association was headed by Taganiya Negat, who emigrated from Ethiopia at a young age and served as the first Ethiopian member of the Israeli parliament (Knesset).

Written testimonies and interviews with old kessoch show that the dilemma of whether to continue the Seged celebrations after the immigration to Israel occupied the kessoch less in the 1990s, and they regarded the Seged celebrations in Israel as a fact. It seems that in the Seged ritual conducted by the "Israel Association of Ethiopian Jews" headed by Taganiya, a fixed and more political ritual was consolidated, which included both traditional and modern elements (Cesana, 1995; Ethiopian holiday in the capital, 1995; Next year in Jerusalem, 1999).

Young social-political activists comprised the dominant stream that led to changes in the Seged and the framework of the community since the 1990s. The reigns of management of the holiday were in the hands of Taganiya, chairman of the "Israel Association of Ethiopian Jews," and he cooperated with heads of young movement of Ethiopian immigrants. The role inversion in conducting the Seged, between these young leaders and the kessoch who were in charge in the past, had significant implications for the contents of the ritual, its structure, and the status of the kessoch during the ritual.

The young leaders wanted to give the holiday renewed content in order to adapt it to the younger generation and to Israeli society. Their motive was not necessarily religious, but rather ethnic-political. They regarded the Seged as a mean for exposing the tradition of the Ethiopian Jews to the Israeli public and for achieving institutional recognition of their unique culture.

Taganiya Negat claimed that the change stemmed from the move to Israel. In his opinion, the holiday cannot be precisely transcribed as it was customary in Ethiopia, and culture must be adapted to the new framework in order to preserve it. He said that every year, after the ritual, many requests are made of him from youths who want a change in the ritual (Sivan \& Fredo, 2002).

The adaptation to which Taganiya referred is not only a strategy for intergenerational connection. Rather, it has implications for the status of the kessoch during the ritual. It means that the youth are becoming more active and involved, contrary to Ethiopia where the ritual was conducted by the older kessoch who had control.

Taganiya was aware of the sensitivity to the kessoch's status in the community on the background of the exclusion of the kessoch by the religious establishment in Israel. He feared losing the symbol of their status and the source of authority which they had left - conducting the Seged holiday. The identification of the social activists of the community, headed by Taganiya, with the community's spiritual leaders, in my opinion curbed drastic changes in the ritual system of the Seged and preserved important parts of its traditional characteristics.

\subsection{Traditional and Modern Elements}

The testimonies and observations show that during the first decade of the $21^{\text {st }}$ century, the holiday had a fixed ritual pattern. The people came en masse to the Government House in Jerusalem from the early hours, in order to celebrate the Seged, including participants who are not members of the Ethiopian community (site of the Israel Association of 
Ethiopian Jews, www.iaej.co.il; Tens of thousands at the Seged, 2005).

Many celebrators came via organized transportation of hundreds of busses. Contrary to Ethiopia, the pilgrimage in Israel is thus not on foot, but rather with vehicles. This is not solely a technical change. Rather, it expresses a deep change in the essence of the pilgrimage as a mean for man's self-denial for forgiveness of his sins.

The adults came while fasting, wearing traditional white clothes. Some placed small stones under the stage that was placed on the mountaintop for the ritual. Although they reached the mountain on busses and not on foot as in Ethiopia, with this symbolic act the celebrators wanted to preserve an ancient custom from Ethiopia, with some change. In Ethiopia, the celebrators who walked up the mountain on the Seged carried a stone on their back or shoulder to symbolize their submission to God on the day of the Seged. When they reached the mountaintop they would place the stone on a wall that surrounded the kessoch's sacred space (Abbink, 1983, p. 793).

Many young people also came: pupils, soldiers, members of youth movements and students. Many of these did not fast. Although this is a day of prayer, many of the youths did not wear modest clothes. The excitement on the faces of all the celebrators who came to the ritual was great, since for them this was a day of meeting their relatives, who upon their immigration to Israel were dispersed around the country.

A large stage, with Israeli flags, was placed overlooking the view from the Government House to the Temple Mount. The kessoch arrived from nine in the morning, wearing white hoods and richly-embroidered robes. Each kess was accompanied by a small colorful procession of men carrying splendorous parasols, which indicated his high status, as well as a person who carried a Torah scroll written in Ge'ez and enveloped by a colorful cloth on his head.

At ten o'clock, the kessoch began praying in the Ge'ez language accompanied by a melody. The prayer was translated by one of the kessoch into Amharic, which the audience understands, and included praises to God for redeeming them from exile, asking for mercy, forgiveness, peace for the state as well as expressions of yearning for the building of the Temple. The audience, mainly the adults, crowded around the kessoch. The excitement of the religious experience was reflected in their eyes.

A minority of the community's youths, mainly the religious ones, stood close to the stage and prayed with the adults. However, many were far from the stage, not only physically. They exploited the day of the Seged as a free day from the army, from studies or from work, for a social encounter and for wandering between the clothing and food stands. Their behavior harmed the essence of the holiday as a day of fasting (To close the atonement circle, 2001; Pikado, 2007; Pikado et al., 2005).

In order to draw the youths to the meanings embedded in Seged and to participate in the celebrations, the organizers, in collaboration with the community's organizations, prepared special activities for the youths, in tents that were put up at the celebration site. Instructors of the "Bnei Akiva" and the "Scouts" youth movements also held activities with their hundreds of cadets, not only from the Ethiopian community (Seged for everyone, 2007).

From noon until one o'clock there was a break in the kessoch's prayer for blessings and speeches of public figures. It was apparent that these were motivated mainly by political needs. They found it important to appear before a large group of potential voters, and tried to ingratiate themselves in their speeches. The politicians' participation also served the political needs of the Ethiopian leaders and social activists, who wanted to use the Seged for obtaining national recognition of the holiday, their culture, their being Jews and Israelis, as well as to demand their rights as equal citizens.

After the speeches, from one to two o'clock, the kessoch again prayed, where the contents of the prayers were praise to God and asking forgiveness. The senior kess preached to those praying about the importance of fulfilling the laws of the Torah and community solidarity and wished the audience that it will celebrate the Seged again next year.

At two o'clock, the ritual ended. Because it was not possible to hold a great feast for so many people at the site of the ritual, the tradition of a shared meal at the end of the prayers for breaking the fast was not preserved as it was in Ethiopia. Some of the older women brought traditional bread (dabo) to the kessoch, which the kessoch blessed, cut into small pieces, ate and divided among the people around them. This was a symbolic ritual, a kind of remnant from the collective meal that was held in Ethiopia headed by the kessoch.

The celebrators who remained accompanied the kessoch with singing and dancing with the Torah scrolls, back to the busses, or in a procession to the Western Wall. The procession headed by the "Bnei Akiva" youth movement was also a symbolic act for the procession of celebrators in Ethiopia, headed by the kessoch, who descended the mountain at the end of the ritual.

\subsection{Opposition to Change and New Religious Interpretation}

The interviews and the written sources show that during the first decade of the $21^{\text {st }}$ century, many of the older spiritual leaders of the community vehemently opposed a change in the holiday, and were greatly hurt by the desire to change the 
tradition which they preserved for centuries. They regarded the Seged as a holy day of prayer, purification, fasting and pleading (Israel Organization of Ethiopian Jews, 2002). Some claimed that they do not see a significant change in the traditional character of the holiday. They admitted that certain changes took place in the Seged in the transition to Israel, but stressed that the holiday was preserved as it was in Ethiopia.

Their difficulty in admitting a change in the tradition is explained in light of Jacob Katz's classical study "Traditional Society and Modern Society" (1960). According to Katz, traditional society, contrary to modern society, is not interested in change and does not aspire to change for fear of harm to its values. When change occurs, its people and leaders settle it in light of tradition, and their trend is to say that the new is the old. A traditional society pretends that no change has taken place in it, and the change does not receive legitimization.

For example, Kess Samai answered, in response to a question on the difference between the ritual in Ethiopia and in Israel:

There is no great difference. The entire course of the ritual did not change. The change is only in that in Israel everyone comes to Jerusalem from all over the country and celebrates together at the Government House, whereas in Ethiopia not everyone gathered in one place. There, the kessoch organized the course of the ritual and set the place of the holiday and the order of the day's activities. The Israelis come to the ritual, and that is good, it shows unity. The ritual itself is intended to be reminiscent of the covenant between God and the People of Israel as they did during the time of Ezra and Nehemiah, and reconfirmed their covenant with God. This is how we continue this tradition also after immigrating to Israel, so that the Temple will be build soon and that all the Jews in the diaspora will return to their Holy Land.

Kess Tagabo indicated:

The Seged holiday is very important for the entire community and also for the People of Israel. This is a holiday that unites and draws us near to each other and to God. We are still found in a test of faith, and hope that next year the Temple will be built. I think it is very important for the community that we have a spiritual holiday. This is a tradition that our forefathers preserved, and we will continue to preserve the holiday. There are changes in the holiday because of the move to Israel, but not fundamental changes. If they exist, they are small changes in the way we celebrate. In Ethiopia the holiday lasted two days (the preparations for the holiday and the ritual itself), and here it is only half a day. But we kessoch still try to maintain it as in the past.

The old kessoch indicate that in their view, the Seged's role did not end after the immigration of the Jews of Ethiopia to Israel, and it first and foremost fulfills an important religious function. However, they, who do not recognize the change, contradicted themselves in affording a new religious interpretation to the holiday: Indeed, our prayers on the Seged to reach the Holy Land were answered, but we must continue to celebrate in order to thank the Lord that we reached Israel, and to pray for the immigration to Israel of the entire Jewish People from the diaspora and the building of the Temple. They also stressed the relevance of the Seged for connecting members of the community to the tradition and culture of the Jews of Ethiopia.

\subsection{The Pan-Jewish Relevance of the Holiday}

After the Seged was recognized as a national holiday in Israel in 2008, I gained the impression that the organizers made great efforts to give the holiday a broad national character. This is apparent in the broader geographic range of the holiday event, i.e. in Jerusalem and also in other places. The events were also expanded in the time dimension: from several weeks before the religious ritual at the Government House to about two months afterward (see, at length, Karash-Hazony, 2009; Israel Association of Ethiopian Jews, 2010; Klein, 2016).

Several events were held before and after the religious ritual, with government and municipal funding, that were not fundamentally religious. For example, the ceremony for beginning the "Seged Holiday" at the President's residence in Jerusalem; music and art nights; holiday events in the education system; the "Sigddiada" festival, and more. It is apparent that the organizers made an effort to disseminate and assimilate the holiday with emphasis on culture, which is a broad common denominator that may draw youths of the community and the Israeli public. A large part of these events became themselves a tradition of the Seged in Israel.

The highlight of the events was the Seged ritual at the Government House promenade, that was performed by the kessoch. Contrary to Ethiopia, the religious ritual conducted by the kessoch was not the main gathering during the ceremony, but rather the speeches, which were usually without a religious content. The kessoch and the community's rabbis did not like this ritual conduct and in the interviews complained that the government ministers and the politicians disrupt the prayers with their speeches, even though this is not intentional. They expressed concern that the Seged day is conducted to a great extent by social activists, and is losing its original religious nature (Afsai, 2014, p. 155).

The kessoch were happy that the Seged turned into an official holiday, but were still worried about its future and 
expressed criticism of its content. Kess Amha expressed concern that the Seged is losing its religious meaning in Israel and is being reduced into a cultural event. He claimed that the Seged ritual in Jerusalem is not only a social gathering, but a day of prayer and introspection, and more should be invested in religious learning days in preparation for the Seged, and less on entertainment, shows and folklore that remove the holiday from its religious context (Afsai, 2014, p. 152).

Kess Mula Zarihon, who served as the spiritual leader of the community of Ethiopian immigrants in Kiryat Ekron, said in a cultural event before the 2012 Seged, that the Ethiopian Jews took the Seged holiday from the Land of Israel and preserved it for generations, and stressed its religious dimension: opportunity to hear about biblical law, strengthening of the faith, yearning for Jerusalem and unity of a Jewish minority in a Christian society. Kess Mula praised the unity with other Jewish communities in the Seged in Israel, and claimed that the Seged should be a holiday for the entire People of Israel (Afsai, 2014, p. 153).

Kess Adago Salaho stressed:

The message of the holiday is that we are all brothers and all Jews are responsible for each other. This day of prayer must be not only for the Jews from Ethiopia, but for an entire nation. It is important that the Seged holiday will expand, and that more people join in its celebration (Afsai, 2014, p. 155).

The claim that the Seged should be adopted by other Jewish communities is a theme that was repeated in the interviews with the spiritual leaders of the community. This was actually a demand for mutual recognition, that in my opinion strengthened following the state's recognition of the Seged holiday.

\subsection{The Strong Black Coffee Band in a Religious Ritual}

While young leaders of the immigrants from Ethiopia stressed the social-national significance of the holiday, it appears that the older kessoch were still stuck in the past. They indicated mainly the religious function of the holiday, and repeated messages on its relevance today (Mangisto, 2014). Kess Wabshet Yalo said: "For a year we wait with yearning for the Seged day to arrive, in order to ascend the mountain in Jerusalem, pray and thank our Lord in Heaven."

Kess Waba Salamon indicated:

We immigrated to the Holy Land and continue to celebrate because we thank God for hearing our prayer, and there is still assimilation of the Jewish people around the world. In addition, this is our holiday and it was recognized as a national holiday. Regarding the youth, they have more awareness of the holiday today, and are interested. Some are less interested. Therefore in the youth movements they explain the essence of the Seged to them. Even non-Ethiopians come and are very interested.

In 2017, the organizers of the Seged celebrations decided, for the first time, to include singer and standup shows in the religious ritual in Jerusalem, out of a desire to adapt it to the spirit of the time and to draw the youths of the community and other groups in Israel. As a consequence of this new perception, the organizers also invited the "Strong Black Coffee" rap band, which symbolizes cultural integration, to appear at the event (Ben David, 2017).

This initiative of the organizers was met with opposition. The sources do not indicate who led it, but it is reasonable to assume that it was directed by the conservative forces in the community, especially the old kessoch. The opponents who demanded cancelling the appearance of the artists in the ritual were successful, and the shows were in the end cancelled a short time before the holiday. The cancellation aroused resentment among the supporters of the organizers' initiative. It is not known who they are, but they are apparently younger members of the community, headed by several young liberal leaders. They claimed that cancellation of artists' shows in the ritual is a missed opportunity that may lead to segregation and distancing of the Ethiopian culture from the Israeli public.

The attempt to include non-religious artistic elements in the religious Seged ritual in Jerusalem did not succeed in 2017. However, it reflects a trend that is strengthening among young activists of the community of inclusion in Israeli society, while calling for recognition of their unique ethnic "otherness." The old kessoch represented the minority opinion that espouses preservation of the traditional nature of the Seged. At the moment, the social-political activists of the community are taking the minority position of the spiritual leadership into account, since they respect it and avoid harming the religious essence of the holiday.

\section{Conclusion}

This article discusses old spiritual leaders of the immigrants from Ethiopia in Israel and focuses on their role in the ritual system of the Seged holiday. The Seged is a pilgrimage holiday which the Ethiopian Jews still celebrate, on November 29. This is a day of fasting, purification and prayer that takes place on high places, during which the religious priests read portions of the Torah and held prayers for redemption and for a return to the Land of Israel.

Every ritual is a planned event, with rules and a hierarchic order that reflects the social structure. The ritual is 
accompanied by the use of symbols, to which Turner refers as being central or dominant because these are symbols that are consistent in their meaning, eternal, and represent the cultural model of the group (Turner \& Turner, 1978, pp. 60, 243-246). Turner also claimed that the influence of the symbolic items is stronger during a pilgrimage, when they are removed from their familiar and regular framework to the new framework (Turner \& Turner, 1978, p. 11).

The schedule of the Seged, similarly to any ritual activity, was fixed, accompanied by symbols. The symbols that are familiar to the Ethiopian Jews from everyday life, that were transcribed to the ritual system of the Seged holiday, also had a great influence on their commitment to the values which these symbols represent. Like any political-social order that affords legitimization to the leadership, the Seged rituals also strengthened the status of the spiritual leadership, since they comprised the main symbol in the ritual system of the Seged and conducted all of its stages (Ben-Dor, 1985, pp. 95-97).

In this article I examined the dynamics of a ritual, which Langer et al. (2006) called "transfer of ritual," and its influence on the "transfer of spiritual leadership" in situations of immigration. The findings indicate that the status of the spiritual leadership of the immigrants from Ethiopia in Israel, as well as the ritual elements that were consolidated in the Seged in the new reality, created a complex liminal situation that integrates between old and new and between old and young leadership which have different perceptions and interpretations.

The oral and written sources show that already during the first Seged celebrations in the early 1980s, the spiritual leaders of the community (the kessoch), who were excluded by the religious establishment from their roles, were also pushed back from their status and responsibility in connection with setting a meaning for the holiday and its nature: whether to celebrate it after their aspiration to immigrate to Israel was realized; where to hold it; the extent to which major ritual characteristics should be preserved.

Since the 1990s, young social-political leaders were the dominant stream in the community who led to changes in the Seged and in the ethnic tradition. The motive of the young leaders was ethnic-political, and they viewed the Seged as a mean for demonstrating ethnic identity, for exposing the community's tradition to the Israeli public, and for achieving institutional recognition of their culture.

The intergenerational role inversion in conducting the Seged had significant implications for the ritual's contents, its structure and the weakening of the kessoch's status. Many of the old kessoch thought that the community's activists went too far in giving a relevant interpretation to the holiday, and the abolishment of important religious characteristics.

The tension between the religious and the social leadership, and the helplessness of the spiritual leadership, continued even after the Seged holiday received national recognition in 2008. The findings show that the organizers made great efforts to give the Seged holiday a broad national nature. This is apparent in a wide dispersion of the holiday events in the geographical space and in the temporal space. The political aspect of the religious ritual was also strengthened, which the kessoch regarded with displeasure and expressed concern that the Seged is losing its religious significance.

In recent years, the initiators' attempt to include artistic shows in the religious ritual in Jerusalem was curbed, by opposition of the kessoch. I therefore conclude that in spite of the decline in their status, and the fact that they take the minority stance in leading the community, the young leaders exhibit sensitivity to the status of the religious leadership and take it into account. In this they try to avoid harming the essence of the Seged as a religious holiday, and also express identification with the kessoch who experience bureaucratic and ethical harm to their status by the establishment.

The issue of the leadership of the immigrants from Ethiopia in Israel in this article has crucial importance in the attempt to understand their organization and coping with the circumstances of immigration as a minority group. The discussion of the spiritual leadership will also turn attention to the social position of immigrants and the elderly in postmodern reality in immigrant-absorbing societies.

Acknowledgments: This research was supported by the Research Committee of Ashkelon Academic College, Israel. I thank the Institute of History and Anthropology of Religions (IHAR), Lausanne University, Switzerland, for inviting me as a guest researcher which enabled me to work on this manuscript.

\section{References}

Abbink, J. (1983). Seged celebration in Ethiopia and Israel: Continuity and change of a Falash religious celebration. Anthropolos, 78, 789-810.

Abbink, J. (1990). The enigma of Beta Esra'el ethnogenesis. An anthro-historical study. Cahiers d'Etudes africaines, 120 (XXX-4), 397-449. https://doi.org/10.3406/cea.1990.1592

Afsai, S. (2014). The Sigd From Ethiopia to Israel. The Reform Jewish Quarterly, 14, 149-168.

Antebi-Yemini, L. (2010). On the margins of visibility: Ethiopian immigrants in Israel. In E. Lomsky-Feder, T. 
Rapoport \& L. Ginsberg (Eds.), Visibility in immigration, pp. 43-68. Jerusalem: Van Leer (Hebrew).

Bass, B. M. (2009). The Bass handbook of leadership. New York, NY: Free Press.

Ben David, S. (2017, November 14). Celebrating the holiday. Maariv, pp. 6-7 (Hebrew).

Ben-Dor, S. (1985). The Seged of Beta Israel. Jerusalem: The Hebrew University (Hebrew).

Ben-Dor, S. (1987). The Sigd of Beta Israel: Testimony to a community in transition. In M. Ashkenazi \& A. Weingrod (Eds.), Ethiopian Jews and Israel, pp. 140-159. New Brunswick, NJ: Transaction Books.

Ben-Dor, S. (2008). Sigd. In H. Salamon (Ed.), Ethiopia, pp. 137-148. Jerusalem: Ben-Zvi Institute (Hebrew).

Ben-Ezer, G. (2010). As a drop that returns to the sea? Visibility and invisibility in the process of absorption of the immigrants from Ethiopia. In E. Lomsky-Feder, T. Rapoport \& L. Ginsberg (Eds.), Visibility in immigration, pp. 328-305. Jerusalem: Van Leer (Hebrew).

Bilu, Y. (2004). Without bounds: The life and death of Rabbi Ya'aqov Wazana. Jerusalem: Magnes (Hebrew).

Brochure of Seged events of the Ethiopian Jews in Israel (2010). Retrieved from cms.education.gov.il/NR/rdonlyres/2F7451EF-623F-4C8E-90E4.../alon.pdf

Cesana, S. (1995, November 23). Holiday and self-scrutiny. Maariv, p. 23 (Hebrew).

Chase, S. (2005). Narrative inquiry. In N. Denzin \& Y. Lincoln (Eds.), The handbook of qualitative research, pp. 651-679. Thousand Oaks, CA: Sage.

Collard, J. (2007). Constructing theory for leadership in intercultural contexts. Journal of Educational Administration, 45(6), 740-755. https://doi.org/10.1108/09578230710829919

Corinaldi, M. (2005). Ethiopian Jewry. Rubin Mass (Hebrew).

Dorfiman, P. W. (1996). International and cross-cultural leadership. In B. J. Punnett \& O. Shenkar (Eds.), Handbook for the international research, pp. 267-349. Oxford, UK: Blackwell.

Ehiopian holiday in the capital. (1995, November 23). Yedioth Aharonoth (Hebrew).

Fry, L. W. (2003). Toward a theory of spiritual leadership. The Leadership Quarterly, 14, 693-724. https://doi.org/10.1016/j.leaqua.2003.09.001

Green, J., Willis, K., Hughes, E., Small, R., Welch, N., Gibbs, L., \& Daly, J. (2007). Generating best evidence from qualitative research: The role of data analysis. Australian and New Zealand Journal of Public Health, 31(6), 545-550. https://doi.org/10.1111/j.1753-6405.2007.00141.x

Hofstede, G. (2001). Culture consequences: Comparing values, behaviors, institutions and organizations across nations. Thousand Oaks, CA: Sage.

Hofstede, G., \& Hofstede, J. (2010). Culture and organizations: The software of the mind. New York, NY: McGraw-Hill.

Israel Association of Ethiopian Jews. (2002). The Seged in Israel. Tel-Aviv (Hebrew).

Israel Association of Ethiopian Jews. (2010). Events of the Seged holiday. cms.education.gov.il/rdonlyres/alon (Hebrew).

Josefsberg Ben-Yehoshua, L. (2013, November 1). Covenant at the top of the mountain. Maariv, pp. 4-5 (Hebrew).

Karash-Hazony, H. (2009, November 20). Holiday of yearnings for Zion. Makor Rishon, pp. 20-21 (Hebrew).

Katz, J. (1960). Traditional society and modern society. Megamot, 10, 304-311 (Hebrew).

Klein, Z. (2016, November 30). The Seged holiday at the Government House: Realization of a dream. NRG News in Israel. https://www.makorrishon.co.il/nrg/online/ART2 (Hebrew).

Langer, R., Lddeckens, D., Radde, K., \& Snoek, J. (2006). Transfer of ritual. Journal of Ritual Studies, 20(1), 1-10.

Maccoby, M. (2009). The leaders we need: And what makes us follow. Tel-Aviv: Matar (Hebrew).

Mangisto, G. (2014). Each with his own Seged. Yedioth Negat, 81, 6 (Hebrew).

Next Year in Jerusalem. (1999, February). Yedioth Negat, 1, 2 (Hebrew).

Oliver-Lumerman, A., Zilber, T., \& de-Shalit, A. (2018). Social leaders in Israel. Jerusalem: Magnes (Hebrew).

Pikado, B. (2007). All of Israel is celebrating. Yedioth Negat, 44, p. 6 (Hebrew).

Pikado, B., Geta, M., Fredo, M., \& Lijishal, I. (2005). A holy day or a social happening. Yedioth Negat, 31, pp. 6-7 
(Hebrew).

Poluda, E. (2007). The world of girls and boys in rural and urban Ethiopia. Addis Abeba: Forum for Social Studies.

Popper, M. (2002). Narcissism and attachment patterns of personalized and socialized charismatic leaders. Journal of Social and Personal Relations, 17(6), 796-808. https://doi.org/10.1177/0265407502196004

Popper, M. (2007). Transformational leadership: A psychological view. Tel-Aviv: Tel Aviv University (Hebrew).

Popper, M. (2012). The followers: A psychological look into the power of attraction to leaders. Tel-Aviv: Ramot, Tel-Aviv University (Hebrew).

Popper, M., \& Maysless, O. (2003). Back to basics: Applying parenting perspective to transformational leadership. Leadership Quarterly, 14, 41-65. https://doi.org/10.1016/S1048-9843(02)00183-2

Seged for everyone. (2007). Yedioth Negat, 39, 6 (Hebrew).

Shalom, S. (2012). From Sinai to Ethiopia. Tel-Aviv: Yediot Aharonot (Hebrew).

Sharaby, R. (2018). We want integration but such that shows our part: Ethnic activism among immigrants' political-social leadership. Advances in Social Sciences Research Journal, 5(12), 154-172. https://doi.org/10.14738/assrj.512.5756

Sharaby, R., \& Kaplan, A. (2014). Like mannequins in a shop window: Leaders of Ethiopian immigrants in Israel. Tel-Aviv: Resling (Hebrew).

Shkedi, A. (2011). The meaning behind the words: Methodologies of qualitative research: Theory and practice. Tel Aviv: Ramot (Hebrew).

Sivan, L., \& Fredo, Z. (2002). Syncretism in the Seged holiday. Seminar paper under supervision of Prof. Rachel Sharaby, in the seminar: Syncretism - Inclusion of cultures as a solution for conflicts. Ashkelon: Ashkelon Academic College (Hebrew).

Spector, S. (2005). Operation Solomon. Oxford: Oxford University Press.

Teferi, A. (2005). About the Jewish identity of Beta Israel. In T. Parfitt \& E. Trevisan Semi (Eds.), Jews of Ethiopia (pp. 173-192). New York, NY: Routledge.

Tens of thousands at the Seged (2005). Pana Lapid - Journal of the Israel Association of Ethiopian Jews, 27, p. 6 (Hebrew).

To close the atonement circle. (2001). Yedioth Negat, 11, 9 (Hebrew).

Turner, V. (1967). The forest of symbols. Ithaca: Cornell University Press.

Turner, V., \& Turner, E. (1978). Image and pilgrimage in Christian culture. Oxford: Basil Blackwell.

Van Mannen, J. (2011). Tales from the field: On writing ethnography. Chicago: Chicago University Press. https://doi.org/10.7208/chicago/9780226849638.001.0001

Weber, M. (1979). On charisma and institution building, selected writings. Jerusalem: The Hebrew University (Hebrew).

\section{Copyrights}

Copyright for this article is retained by the author(s), with first publication rights granted to the journal.

This is an open-access article distributed under the terms and conditions of the Creative Commons Attribution license which permits unrestricted use, distribution, and reproduction in any medium, provided the original work is properly cited. 